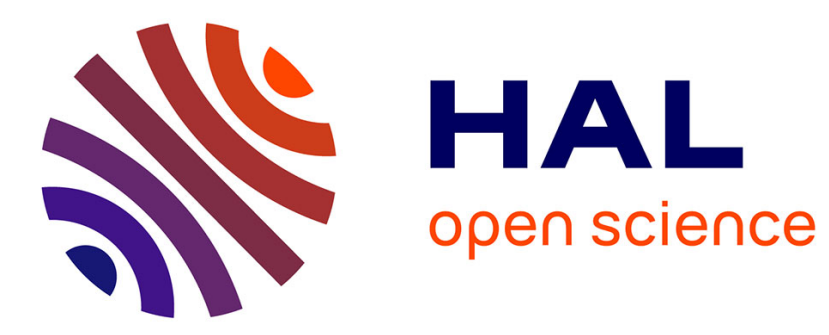

\title{
Timescale of open-reservoir evolution beneath the south Cleft segment, Juan de Fuca ridge
}

Carole Cordier, Martial Caroff, Eric Rannou

\section{To cite this version:}

Carole Cordier, Martial Caroff, Eric Rannou. Timescale of open-reservoir evolution beneath the south Cleft segment, Juan de Fuca ridge. Mineralogy and Petrology, 2012, 104 (1-2), pp.1-14. 10.1007/s00710-011-0159-5 . insu-00617942

\section{HAL Id: insu-00617942 \\ https://hal-insu.archives-ouvertes.fr/insu-00617942}

Submitted on 31 Aug 2011

HAL is a multi-disciplinary open access archive for the deposit and dissemination of scientific research documents, whether they are published or not. The documents may come from teaching and research institutions in France or abroad, or from public or private research centers.
L'archive ouverte pluridisciplinaire HAL, est destinée au dépôt et à la diffusion de documents scientifiques de niveau recherche, publiés ou non, émanant des établissements d'enseignement et de recherche français ou étrangers, des laboratoires publics ou privés. 


\section{Timescale of open-reservoir evolution beneath the south Cleft} segment, Juan de Fuca ridge.

C. Cordier $(\bowtie)$ and M. Caroff

12 Université Européenne de Bretagne, Université de Brest; UMR n 6538 "Domaines

13 Océaniques" et IUEM; 6 avenue Le Gorgeu, C.S. 93837,

1429238 Brest Cedex 3, France.

15 E_mail: cordier@.unisi.it

17 C. Cordier

18 Present address: Museo Nazionale dell'Antartide, Universita di Siena, Via Laterina 8, 1953100 Siena, Italy.

21 E. Rannou

22 Université Européenne de Bretagne, Université de Brest; UMR n6205 “Laboratoire de

23 Mathématiques"; 6 avenue Le Gorgeu, C.S. 93837,

2429238 Brest Cedex 3, France. 
Abstract Lavas erupted at the southern end of the intermediate Juan de Fuca ridge (Cleft segment) are mostly cogenetic and their chemical diversity results from melt evolution in an open magma system. In the present study, we apply a theoretical model allowing the time evolution of this periodically recharged and tapped magma chamber to be estimated. In our mathematical procedure, the melt quantity supplied to the reservoir varies through time following a sinusoidal function. The rare earth element concentrations in the refilling melt were calculated on the basis of the REE distribution in lavas. This theoretical composition is akin to that previously estimated for a Mg\#70 MORB from mineralogical and chemical data. Then, we approached the temporal evolution of the reservoir using a set of suitable parameters deduced from the geometry of the crust and magma system beneath the Cleft segment. Particularly, we considered two end-members scenarios for the melt repartition through the magma reservoir beneath the Cleft segment: the "gabbro glacier" model (crystal nucleation and growth occur within one single melt lens and crystals subside vertically and laterally) and the "sheeted sill" model (crystallization takes place within a network of connected sills located at various depths in the crust). We estimated that the magma chamber is refilled every thousand years and that the melt resides approximately one hundred years within the reservoir.

Keywords: oceanic crust; mid-ocean ridge basalts; magmatic periodicity; open-system reservoir; replenishment melt; residence time

\section{Introduction}

To develop quantitative models for magmatic systems beneath fast- and intermediatespreading ridges, constraints on the timescales of processes such as melting, differentiation, 
and crystallization are required. Temporal information is still difficult to estimate from geological and geochemical data. For two decades, more and more studies were based on samples collected from holes drilled into the upper oceanic crust (Wilson et al. 2006), from across-ridge profiles (Davis et al. 2008), from crust exposures along slightly tectonized fracture zones or propagating rifts (Karson et al. 2002a; Karson et al. 2002b; Pollock et al. 2005; Cordier et al. 2007), and from ophiolite exposures (Pallister and Hopson 1981;

Smewing 1981; Einaudi et al. 2003). These studies provided constraints on the relative chronology of the volcanics and then on the time-related chemical variations in lavas erupted from a single ridge segment. Further seismological data have shown that, beneath spreading ridges, the melt lens is a dynamic object. Its volume and depth are tied to the eruption and replenishment cycles of the magma reservoir (Hussenoeder et al. 1996; Hooft et al. 1997; Singh et al. 1998). The vertical movements of the melt lens were also documented by petrological evidences of reheating, hydrous partial melting and assimilation of the base of the sheeted dikes (Gillis and Coogan 2002; Koepke et al. 2008; France et al. 2010). On the whole, these results evidence cyclic variations of the thermal state of the axial magma chamber, related to fluctuations of the balance between magma recharge and hydrothermal cooling beneath spreading ridges.

We propose here to characterize the rare earth element (REE) concentrations in melts that evolved in a postulated periodically refilled reservoir and to estimate the REE composition of the replenishment melt, the average crystallization rate, the period of magma recharge and the average magma residence time, using the mathematical procedure developed by Rannou et al. (2006). We will consider the lavas erupted at the southern end of Juan de Fuca ridge axis: those collected at and near the axis (Smith et al. 1994; Stakes et al. 2006) and those collected along the northern wall of the Western Blanco Depression, which truncates the crust accreted at the Juan de Fuca axis since 1.4 Ma (Cordier et al. 2007). In addition to 
chemical data, the model resolution requires the estimation of some geological parameters (Fig. 1) related to the architecture of the crust and to the geometry of the magma reservoir. A broad approach of these parameters has already been discussed by Rannou et al. (2006). Here, their estimation will be made to consider the specificities of the reservoir beneath fast- and intermediate-spreading ridges. Indeed, it is well-established that beneath these ridges, the axial magma chamber includes one or several thin lens(es) of partially crystallized melt located just below the sheeted dike complex and overlying a partially molten region (Detrick et al. 1987; Sinton and Detrick 1992; Boudier et al. 1996). However, the role of this (these) melt lens(es) in the storage and differentiation of mid-ocean ridge basalts (MORBs) and in the accretion of the lower crust is still debated. The current models are represented by two endmembers. According to the "gabbro glacier" model (GG, Fig. 1b), crystal nucleation and growth occur within one single melt lens and crystals subside vertically and laterally to form the lower crust as oceanic crust spreads away from the ridge axis (Henstock et al. 1993; Phipps Morgan and Chen 1993; Quick and Denlinger 1993; Henstock 2002). Conversely, the "sheeted sill" model (SS, Fig. 1c) considers that crystallization takes place in situ within a network of connected sills located at various depths in the crust and that the seismically imaged melt lens is simply the shallowest of them (Boudier et al. 1996; Kelemen et al. 1997; Korenaga and Kelemen 1998; Garrido et al. 2001). The relative efficiency of these two scenarios depends on the cooling rate of the lower oceanic crust and thus on the interplay between heat supply through melt recharge and heat extraction through conduction and hydrothermal circulations. In turn, these models have diverging consequences on the repartition of the amount of crystallization with depth and on the expected degree of differentiation of the melt refilling the upper melt lens. For example, if heat removal by hydrothermal circulations is more efficient from the base of the dyke complex than from deeper in the lower crust, the majority of crystallization probably will occur in the upper melt 
100 lens rather than in situ within the gabbroic section. In this case, primitive melts will be

101 delivered to the upper lens. In our modeling, we thus evaluated the role of in situ crystallization and, through the quantity of melt in the magma chamber, the respective contribution of the upper melt lens and of the lower sills during magma differentiation.

\section{Open magma system beneath the southern Cleft segment of the Juan de Fuca ridge}

Recent evolution documented by the geochemistry of the Cleft lavas

110 Its southern $60 \mathrm{~km}$-long Cleft segment $\left(45^{\circ} 03^{\prime} \mathrm{N}\right.$ to $\left.44^{\circ} 27^{\prime} \mathrm{N}\right)$ spreads at an intermediate rate

111 (56 mm/y, Wilson 1993) and is bounded by the Vance segment on the north and the Blanco

112 fracture zone on the south (Fig. 2a). The segment axis is characterized by a dome rifted by a

113 large transient graben (Normark et al. 1983). Along the southern part of the segment, the

114 graben floor is notched by a central narrow depression, named cleft or axial summit collapse

115 trough, which results from the collapse of volcanic structures, lava lakes or thick volcanic

116 flows (Chadwick and Embley 1998; Stakes et al. 2006). The roof of discrete melt lenses has

117 been seismically imaged at $\sim 2 \mathrm{~km}$ of depth into the crust and over $10 \mathrm{~km}$-long continuous

118 intervals (Canales et al. 2005; Canales et al. 2006). In the southern part of the Cleft segment,

119 the melt lens would be 100-m thick and 900-m wide and partially crystallized, comprising

120 only 30 vol. \% of melt (Canales et al. 2006).

121 The Cleft lavas are normal MORBs resulting from the partial melting of a depleted

122 and quite homogeneous mantle source with constant melting extents (Smith et al. 1994;

123 Stakes et al. 2006). The lavas display a large range of compositions (3.5 $<\mathrm{MgO}$ wt. \% $<$,

124 Fig. 2b) that are thought to mostly result from the differentiation of primary tholeiitic melts in 
open-system magma reservoirs (Fig. 2c). The correlation between lava ages, degrees of

126 differentiation, and latitudes (Fig. 2b, Smith et al. 1994) is consistent with the coexistence of several discrete magma chambers along the Cleft segment, as observed in seismic profiles (Canales et al. 2005), and with the increase of the melt lens crystallinity from north to south inferred from geophysical studies (Canales et al. 2006). In the northern part, young and

130 primitive basalts prevail (Fig. 2b) and would originate from a recently recharged magma

131 reservoir. Southward, lavas are more evolved (Fig. 2b) and would derive from a progressively

132 waned chamber, in response of the decrease of the magma supply (Smith et al. 1994). Thus,

133 along the segment, the magma chambers are in different stage of evolution, which can be

134 interpreted as reflecting the cyclic evolution through time of the axial magma reservoirs, as

135 already proposed for the East Pacific Rise by Lagabrielle and Cormier (1999) and for the

136 north-south propagating spreading center of the North Fiji Basin by Caroff and Fleutelot 137 (2003).

138 The southernmost magma chamber that we study is interpreted to be in a waning state.

139 Dacitic glass has been collected at the intersection between the southern Cleft segment and

140 the Blanco fracture zone (Fig. 2). The dacitic melt could correspond to a differentiated

141 product erupted from cooler and distal edges of the melt lens while the composition in the

142 central part of the lens was buffered by replenishment (Stakes et al. 2006). However,

143 Cotsonika et al. (2005) proposed that dacitic melts might result from contamination of basaltic

144 resident melts by rhyolitic ones issued from the partial melting of the hydrated basaltic crust.

145 More recently, Wanless et al. (2010) suggested that MOR dacites result from extensive

146 fractional crystallization combined with partial melting and assimilation of amphibole-bearing 147 altered crust.

149 Past evolution documented by the Western Blanco Depression lavas 
151 At the southern tip of the Cleft segment, the northern wall of the Western Blanco Depression

152 (Fig. 2a) provides a window through the slightly tectonized upper oceanic crust accreted for

153 1.4 Ma to the north of the ridge-transform intersection (Wilson et al. 1984; Embley and

154 Wilson 1992; Juteau et al. 1995; Karson et al. 2002b; Fig. 3a). A thick volcanic unit, made of 155 basaltic pillow-lavas, massive flows, and sparse feeder dikes (Juteau et al. 1995; Karson et al.

156 2002b), overlies an intensively hydrothermalized sheeted-dike complex (Manac'h et al. 1999).

157 The northern scarp provides an opportunity to study the temporal variations of the lava

158 composition by considering that the vertical succession of the lavas records increasing ages

159 with depth (Tivey et al. 1998; Pollock et al. 2005; Cordier et al. 2007; Fig. 3a).

160 Cordier et al. (2007) have shown that the lavas outcropping along the Northern Scarp

161 are mostly cogenetic. The conclusions of their petrological and geochemical study confirmed

162 that beneath the southern tip of the Cleft segment: (i) the melt evolution occurs in a complex

163 magma chamber, with differentiated, $\mathrm{H}_{2} \mathrm{O}$-rich compositions achieved in the cooler

164 solidification zones; (ii) the differentiation mainly results from fractional crystallization,

165 coupled with magma mixing between basaltic and intermediate melts; (iii) the mixing events

166 reveal the periodic recharge of the reservoir by mafic melts $(\mathrm{Mg \# =70)}$ and this regime has

167 governed the magmatic system over the last $~ 1.4 \mathrm{Ma}$ (Fig. 3b).

168 These results on the lavas erupted both at the present time (Smith et al. 1994; Stakes et

169 al. 2006) and over the last $1.4 \mathrm{Ma}$ (Cordier et al. 2007) show that the magma chamber beneath

170 the southern end of the Cleft segment fulfills the conditions required to apply the model of

171 Rannou et al. (2006): (i) the chemical variations in the collected lavas derive from reservoir

172 differentiation and the chemical effects attributable either to the mantle source heterogeneity

173 or to variations of the melting degree can be considered negligible (Smith et al. 1994), except

174 perhaps for the dacite genesis (Wanless et al. 2010); (ii) the time evolution of the processes 
occurring in the reservoir can be approached from the spatial distribution of the lava chemistry, along the length of the Cleft segment (Fig. 2b) or vertically (Fig. 3b) along the Northern Scarp (Smith et al. 1994; Pollock et al. 2005; Cordier et al. 2007); (iii) the magma chamber has evolved in open system, with periodic melt inputs (Cordier et al. 2007).

179

\section{Geomathematical modeling of the temporal evolution of the magma chamber beneath}

\section{the southern Cleft segment}

Properties and resolution steps of the model

In the next sections, we will approach the variations of melt quantities and compositions during the evolution of a periodically replenished and tapped steady-state magma chamber through differential equations, by using the model developed by Rannou et al. (2006). Incompatible trace elements (here rare earth elements) are especially suitable for such a modeling. The behavior of compatible elements is too much dependent on both the nature and the proportion of the fractionating minerals. The originality of the model comes from the use of a sinusoidal function to reproduce the continuous and smoothed variations through time of the quantity of melt refilling the reservoir. The volume of resident melt varies in response to the intrusion and controls the crystallized and extruded volumes (Fig. 1a). Rannou et al. (2006) showed that for a steady-state reservoir, the REE concentrations in melts expelled from such a reservoir vary continuously through time following a sinusoidal curve.

Concentrations in incompatible elements are minimal just after the recharge of the system by mafic melts, and they progressively increase due to the fractional crystallization occurring between two recharge events. This approach reconciles both concepts about the open-system magma chambers, usually treated separately: periodic inputs (O’Hara 1977; O’Hara and 
Mathews 1981) and continuous inputs (De Paolo 1981; Reagan et al. 1987). Here, indeed, the 201 input is continuous but occurs at different rates. Rannou et al. (2006) demonstrated that this model is especially suitable for modeling

203 the evolution of natural systems since it isolates the signals that are geologically significant.

204 For example, in a reservoir that is periodically recharged by melt of near constant

205 composition, the effects of natural disturbances in the replenishment cycles are strongly 206 attenuated and do not perturb significantly the calculated variation through time of the lava composition (Rannou et al. 2006: their Fig. 3). Noises in the input function behave like a high-frequency signal, attenuated by the magmatic system. In the same way, an occasional and short variation of the incompatible trace element composition of the refilling melt, traducing for instance a sudden wall-rock contamination, does not significantly modify the 211 modeled composition of the lavas that evolve in the system. For example, Rannou et al. 212 (2006) have considered a magmatic system assimilating a quantity of rocks (leucosome with $12 \mathrm{ppm} \mathrm{Ce}$ ) corresponding to $10 \%$ of the incoming melt (MORB with $3 \mathrm{ppm} \mathrm{Ce}$ ) during a

214 fifth of the period. The difference in output Ce concentrations does not exceed $7 \%$ with 215 respect to the assimilation-free model: the lava concentration peak increases from 17.2 to 18.3 216 ppm of Ce just after the event, then to a damped value of $17.8 \mathrm{ppm}$ at the following cycle. 217 These properties thus allow considering a smoothed, mathematically simple sinusoid to model 218 the magma recharge.

220 different parameters and their units are listed in Table 1. The first resolution step requires the 221 estimation of: - the incompatible trace element concentrations in the cogenetic lavas that bound the compositional range of the dataset, regarded as representative of the expelled liquids during

224 the open-system evolution of the reservoir $\left(C^{\mathrm{E}}{ }_{\min }\right.$ and $C^{\mathrm{E}}{ }_{\max }$ for the element $\mathrm{E}$, Table 1); 
- the distribution coefficients between the global solid that crystallized and the melt $\left(D^{\mathrm{E}}\right)$

- the ratio between expulsion and crystallization rates $\left(r_{\mathrm{e}}\right)$.

We introduced an additional parameter with respect to the model of Rannou et al. (2006) to take into account the complexity of the differentiation in the composite magma chambers beneath the spreading ridges. Indeed, the interstitial residual melts of the crystal mush zones can be extracted and mix with the resident melt. The chemical evolution resulting from such a mechanism - if exists - certainly differs from the pure fractional crystallization process, as considered by Rannou et al. (2006). Thus, we considered the reinjection into the melt lens of a fraction $f$ of interstitial liquid that has evolved within the partially solidified zones (Table 1). The equations are adapted from Langmuir (1989) by replacing the bulk distribution coefficient $D^{\mathrm{E}}$ by the parameter $z^{\mathrm{E}}$ (Table 1 and Eq. 2 of Fig. 4). As expressed, $z^{\mathrm{E}}$ models possible chemical exchanges between interstitial liquids and surrounding crystals (Langmuir 1989). Caroff (1995) named imperfect fractional crystallization this mechanism of solutal convection with mineralogical reactions, the principles of which being close to those of the reactive crystallization model of Collier and Kelemen (2010).

The different data are introduced into Eq. 1 of Fig. 4, in which all the parameters are considered constant through time. In a first step, for each REE, we run iteratively the Eq. 1 with different values of $C_{\mathrm{i}}^{\mathrm{E}}$ and $\beta^{\mathrm{E}}$ (internal parameter, see Table 1 and Rannou et al. 2006) until the maximum and minimum concentrations that are modeled match those measured in lavas (Rannou et al. 2006). The replenishment pulsation $(\omega)$ is arbitrarily fixed for this first step as it has no effect on the calculated $C^{\mathrm{E}}$ values. This is equivalent to model the variations of $C^{\mathrm{E}}$ in function of a dimensionless time. The REE concentrations in the replenishment melt $\left(C_{\mathrm{i}}^{\mathrm{E}}\right)$ and the $\beta^{\mathrm{E}}$ value for each REE are estimated. The average of the $\beta^{\mathrm{E}}$ values calculated for all the considered REE $\left(\beta_{\mathrm{av}}\right)$ corresponds to the ratio between the replenishment pulsation and 
the crystallization rate (Table 1). The good reproducibility of the $\beta^{\mathrm{E}}$ values, i.e. a low standard deviation on their average $\sigma\left(\beta_{\mathrm{av}}\right)$, is then used to validate the set of distribution coefficients. The second step of the modeling requires the estimation of the mean rate of melt injection $\left[q_{\mathrm{i}}\right]$ into the reservoir and of the variation of the quantity (here expressed as volume) of resident melt during a cycle $\left(Q_{\max }-Q_{\min }\right)$. These parameters are introduced in Eqs. 3-5 (Fig. 4), together with $r_{\mathrm{e}}$ and $\beta_{\mathrm{av}}$, to calculate the fraction of melt crystallized by year $(\alpha)$, the period of the replenishment $(T)$, and the mean residence time of the melt within the reservoir ( $\tau$ ). By introducing these results in Eq. 6 (Fig. 4), we model the temporal variations of the resident melt volume.

The curves of Fig. 5 illustrate the effects of the variation of some parameters

260 introduced into the modeling $\left(C^{\mathrm{E}}{ }_{\max }, f, Q_{\max }-Q_{\min }\right)$ on the calculated compositions of melt expelled from the periodically recharged reservoir (from Eq. 1: Fig. 5a, b) and on the volumes of resident melt (from Eq. 6: Fig. 5c, d).

Procedure applied to the magma system beneath the southern Cleft segment

Model parameter estimation

Our calculations are only based on rare earth elements (REE) because (i) these elements have been extensively analyzed in the available samples, (ii) their concentrations have not been significantly modified during subsequent seawater alteration, and (iii) their individual 271 mineral/liquid distribution coefficients are quite well constrained from literature data. Along 272 the Northern Scarp, Cordier et al. (2007) defined a cogenetic suite that extends from the mafic 273 basalt BV2960-7 (MgO 8.1 wt.\%) to the ferrobasalt BN02-12 (MgO 4.32 wt.\%), both 274 aphyric (Figs 2c and 6). We used these two samples to approach $C^{\mathrm{E}}$ min and $C^{\mathrm{E}}{ }_{\max }$, respectively 
(Table 2). However, Cordier et al. (2007) found that some ferrobasalts might result from mixing between dacitic residual melts ( $\mathrm{MgO} 1.1 \mathrm{wt} . \%)$ and mafic melts ( $\mathrm{MgO} 8.5 \mathrm{wt} . \%)$. Even if such a hypothesis is judged unlikely in recent studies, such as Wanless et al. (2010), a second set of calculations has been performed using a more evolved $C^{\mathrm{E}}{ }_{\max }$ end-member, in view to test the response of the model to a variation of the chemical parameters introduced into Eq. 1 of Fig. 4. All along the south Cleft segment, the only dacitic glass has been sampled by Stakes et al. (2006) but has not been analyzed for REE by these authors (Table 2, Fig. 2, sample RC10). Consequently, we used the composition of an andesite collected on the Galapagos Spreading Center (Fornari et al. 1983; Perfit et al. 1983), that has REE pattern parallel to the Northern Scarp ferrobasalts (Table 2 and Fig. 6a).

The next parameter, $r_{\mathrm{e}}$ (Table 1), has been approximated following the method proposed by Rannou et al. (2006) as the ratio between the thicknesses of the basaltic and gabbroic layers of the oceanic crust (Figs. $1 \mathrm{~b}$ and c). Assuming that the gabbros extend from the seismically imaged melt lens to the Moho, the ratio of the melt lens depth $(2 \mathrm{~km}$, Canales et al. 2005) to the thickness of the plutonic complex (5 km, West et al. 2003) provides a $r_{\mathrm{e}}$ ratio equal to 0.4 .

The REE bulk distribution coefficients have been calculated by weighting the individual mineral/liquid distribution coefficients of the mineral phases (Agee 1990; Fujimaki et al. 1984) by their appropriate proportion in the global crystallizing assemblage. For a differentiation leading to ferrobasalts, the phase proportions are determined for a Fe-Ti oxidefree gabbroic cumulate $\left(D_{1}{ }^{\mathrm{E}}\right.$, Table 2$)$. For an andesitic term, the crystallizing assemblage includes Fe-Ti oxides, as suggested by the drastic drop in the $\mathrm{TiO}_{2}$ content observed in the Fig. 3 diagram, and apatite $\left(D_{2}{ }^{\mathrm{E}}\right.$, Table 2).

By varying the $f$ value from 0 to 1 , we can describe all the cases ranging from perfect equilibrium (restricted to the solidification zone) to perfect fractional crystallization. The 
300

procedure described by Rannou et al. (2006) presupposes a $f$ value equal to $1\left(z^{\mathrm{E}}=D^{\mathrm{E}}\right)$. In our calculations, we also tested the model with a value of $f$ of 0.5 .

The last parameters to be estimated are the melt quantities, here expressed as volumes. Beneath the Cleft segment, the distribution of the axial crustal reflector imaging the melt lens shows that the magma chamber is continuous over 5 to $10 \mathrm{~km}$-long intervals, even if its characteristics (depth and crystallinity) vary with shorter wavelength (Canales et al. 2005). It is likely that the scale of the magma chamber segmentation has not changed significantly over the last thousands of years. Thus, we calculated the different melt volumes introduced in the model resolution by considering a 10-km long magma chamber.

The mean rate of melt injection $\left[q_{\mathrm{i}}\right]$ is regarded as the volume of crust accreted per year. For a $7 \mathrm{~km}$-thick crust (West et al. 2003) and a full spreading rate of $56 \mathrm{~mm} / \mathrm{yr}$ (Wilson 1993), [ $\left.q_{\mathrm{i}}\right]$ is equal to $0.004 \mathrm{~km}^{3} /(\mathrm{yr} .10 \mathrm{~km})$.

The variation of the volume of resident melt during a cycle $\left(Q_{\max }-Q_{\min }\right)$ is the least precisely estimated, because it requires assumptions on the quantity of melt expellable from the magmatic system and thus on the melt distribution over the crust thickness beneath the ridge axis. Beneath the southern part of the Cleft segment, given the lens size and crystallinity deduced from seismic data (Canales et al. 2005, 2006), the quantity of melt that can be expelled from the uppermost, seismically imaged and partially crystallized lens (gabbro glacier model GG1, Fig. 1b) during the time interval of inflation and deflation of the magma chamber is ca. $0.45 \mathrm{~km}^{3}$ (Table 3). We also run the calculations with a higher volume of melt $\left(0.63 \mathrm{~km}^{3} / 10 \mathrm{~km}, \mathrm{GG} 2\right.$, Fig. $1 \mathrm{~b}$ and Table 3$)$ to consider the partial draining of the interstitial melt from the mushy solidification zones to the melt lens during compaction of the magma chamber (Lagabrielle and Cormier 1999). Finally, we made an attempt to estimate the volume of melt expellable from several sheeted sills distributed all over the crust thickness (SS model, Fig. 1c). However, no geophysical results can be actually used to decide how many sills lie in 
depth and how these sills contribute to the magma chamber tapping. We arbitrarily considered that no more than a second melt lens is affected by the melt tapping, assigning a value of 0.9 $\mathrm{km}^{3} / 10 \mathrm{~km}$ to the parameter $Q_{\max }-Q_{\min }$ (Table 3).

Results

The geochemical and temporal results of the modeling applied to the magma system beneath the southern Cleft segment are shown in Table 3 and in Figs 5-6. The consistency of the set of $D^{\mathrm{E}}\left(\right.$ and $\left.z^{\mathrm{E}}\right)$ coefficients, and consequently the validity of the calculated $C_{\mathrm{i}}^{\mathrm{E}}$, is attested by the good reproducibility of the $\beta^{\mathrm{E}}$ values calculated for the different REE (Table 3), as shown by the low $\sigma\left(\beta_{\text {av }}\right)$ values (ranging from 0.119 to 0.200 , Table 3$)$. For a $f$ value of 1 , the $C_{\mathrm{i}}^{\mathrm{E}}$ values calculated from the ferrobasalt and andesite composition to approach $C^{\mathrm{E}}{ }_{\max }$ are fairly similar

337 (Table 3 and Fig. 6b). The $C_{\mathrm{i}}^{\mathrm{E}}$ patterns have lower REE contents and are slightly more 338 depleted in light REE relative to lavas. The pattern of the primary melt with $\mathrm{Mg \# =70}$ 339 determined by Cordier et al. (2007) is very close to and bracketed by the two theoretical 340 refilling melt compositions (Fig. 6b). This similarity confirms that the modeled replenishment 341 liquid can be regarded as a primary melt. value to model a low melt flow from the solidification zones to the main magma lens 344 (Langmuir 1989, Caroff 1995). Indeed, for most of the REE (except La and Nd), the modeled 345 composition of expelled melts does not match the observed composition range. This result 346 might support that andesite/dacite compositions cannot be achieved by pure MORB fractional 347 crystallization, consistently with the Wanless et al. (2010) conclusions. For the differentiation 348 leading to ferrobasalts, introducing a $f$ value of 0.5 results in $C_{i}^{\mathrm{E}}$ values slightly higher than 
349 for perfect fractional crystallization $\left(f=1\right.$, Fig. 5b), without significant increase of the $\beta^{\mathrm{E}}$ 350 variability $\left(\sigma\left(\beta_{\mathrm{av}}\right)=0.124\right.$, Table 3$)$.

When calculating the temporal data, the only varying parameters are $\beta_{\mathrm{av}}$ and $Q_{\max }-Q_{\min }$

352 (Eqs 3-5, Fig. 4). Low $\beta_{\mathrm{av}}$, resulting either from high $C^{\mathrm{E}}{ }_{\max }$ or from low $f$ values (Table 1,

353 Step 1), produces high average crystallization rate $\alpha$, high replenishment period $T$, and low

354 average melt residence time $\tau$ (Fig. 5a, b and Table 3, Step 2). Conversely, an increase of the

355 variation of the magma chamber volume during a cycle $\left(Q_{\max }-Q_{\min }\right)$ results in a diminution of

$356 \alpha$ and an increase of both $T$ and $\tau$ (Fig. 5c, d and Table 3, Step 2). Thus, considering a

357 reservoir with a well-established thermal regime, the more the volume of interconnected (i.e.

358 expellable) liquids is high the more the time required for magma differentiation is long. As

359 the temporal results are very sensitive to the $Q_{\max }-Q_{\min }$ value (Fig. 5 and Table 3 ), they

360 strongly depend on the assumptions about the quantity of expellable melt.

361 The volume of melt in the reservoir oscillates through time with inflation plus

362 deflation cycles of 550 to 2250 years, in function of the values ascribed to the chemical and

363 geological parameters (Table 3 and Fig. 5). In average, melts reside 60 to 150 years in the

364 magma chamber (Table 3). The variation range of the calculated magma residence times is

365 close to that determined using Ra-Th disequilibria (tens to thousands years) for basaltic to

366 andesitic magmas that have evolved in steady-state, well mixed, open-reservoirs (Pyle 1992).

367 However, the temporal results of this modeling can hardly be validated by direct comparison

368 with radiochronological data measured on the studied samples. First, we cannot estimate the

369 cycle period by dating the mafic samples that bracket a chemical cycle. Current datation

370 methods have not a sufficient time resolution (e.g. magnetic isochrones, Fig. 3), they are

371 difficult to apply to tholeiites (e.g. K/Ar and ${ }^{40} \mathrm{Ar} /{ }^{39} \mathrm{Ar}$ methods), or they are not suitable for

372 the considered lavas that are older than about $300 \mathrm{Ka}$ (e.g. ${ }^{230} \mathrm{Th} /{ }^{238} \mathrm{U}$, Fig. 2). Second, our

373 samples are too old (> 8,000 years) to still record the ${ }^{226} \mathrm{Ra}^{230}{ }^{230}$ or ${ }^{210} \mathrm{~Pb}-{ }^{226} \mathrm{Ra}$ disequilibria, 
374 which are generally used to estimate the magma residence time in spreading ridge context

375 (Cooper et al. 2003; Goldstein et al. 1993; Rubin and MacDougall 1990; Rubin et al. 2005;

376 Volpe and Goldstein 1993).

\section{Conclusions}

380 In this study, we attempted to model the time evolution of the periodically recharged magma 381 chamber beneath the southern tip of the Cleft spreading segment. First, Rannou et al. (2006) 382 developed a realistic mathematical procedure to model the geochemical evolution of changing 383 volume magma chambers, periodically recharged and tapped. Subsequently, in their study on 384 the lavas exposed along the northern wall of the Western Blanco Depression, Cordier et al. 385 (2007) highlighted a complex chemical evolution with depth, interpreted as the result of periodic replenishment of the southernmost magma reservoir of the Cleft segment. segment. The composition of the replenishment melt that we modeled is consistent with that obtained from mineralogical and chemical data for a $M g \#=70$ melt (Cordier et al. 2007). This reproducibility between theoretical and experimental compositions, already shown by Rannou et al. (2006) in their application to North Fiji Basin lavas, validates the first step of the modeling. In addition, by introducing geological parameters in the modeling procedure, we estimated that the magma chamber is refilled every $1,100 \pm 500$ years and that the melt

394 resides $\sim 100$ years within the reservoir beneath the southern Cleft segment. These temporal 395 results are close to those calculated in a same way for the ultra-fast spreading East Pacific 396 ridge (period $T=750$ years and magma residence time $\tau=300$ years; Rannou et al. 2006). This study demonstrates the applicability of the model of Rannou et al. (2006) to 398 magma reservoirs beneath spreading ridges. Once the periodic evolution of the magma 
chamber demonstrated, it can be used to approach the composition of the replenishment melt.

400 Besides, its application to sites where conventional dating methods are not relevant is an 401 auxiliary approach to access the periodicity of the magmatic cycles and the melt residence

402 time. The result accuracy depends on the precision when estimating the variable parameters, 403 from geological and geochemical data. Inversely, for sites where our theoretical approach 404 could be combined with radiochronological data, such a combination could bring new 405 constraints on some of the data used for the model resolution and consequently on the 406 subjacent assumptions about the magma system. For example, the volume of melt expellable 407 from the magmatic system $\left(Q_{\max }-Q_{\min }\right)$ could then be stated and the models of lower oceanic 408 crust accretion be discriminated.

409

410 Acknowledgments: We acknowledge Johann G. Raith for editorial assistance and Wendy 411 Bohrson for reviewing this work.

\section{References}

Agee CB (1990) A new look at differentiation of the Earth from melting experiments on the Allende meteorite. Nature, 346: 834-837

417 Boudier F, Nicolas A, Ildefonse B (1996) Magma chambers in the Oman ophiolite: Fed from the top or from the bottom? Earth and Planetary Science Letters 144: 239-250 Nedimovic MR, Van Ark E (2005) Upper crustal structure and axial topography at intermediate spreading ridges: Seismic constraints from the southern Juan de Fuca ridge. Journal of Geophysical Research, 110, B12104, doi: 10.1029/2005JB003630 
Canales JP, Singh SC, Detrick RS, Carbotte SM, Harding AJ, Kent GM, Diebold JB, Babcock JM, Nedimovic MR (2006) Seismic evidence for variations in axial magma chamber properties along the southern Juan de Fuca Ridge. Earth and Planetary Science Letters 246: $353-366$

Caroff M (1995) Open system crystallization and mixing in two-layers magma chambers. Lithos 36: 85-102

Caroff M, Fleutelot C (2003) The north-south propagating spreading center of the North Fiji Basin. Modeling of the geochemical evolution in periodically replenished and tapped magma chambers. Mineralogy and Petrology 79: 203-224

Chadwick W, Embley, RW (1998) Graben formation associated with recent dike intrusions and volcanic eruptions on the mid-ocean ridge. Journal of Geophysical Research 103: 9807-9825

Collier ML, Kelemen PB (2010) The case for reactive crystallization at Mid-Ocean Ridges. Journal of Petrology 51: 1913-1940

Cooper KM, Goldstein SJ, Sims KWW, Murrell MT (2003) Uranium-series chronology of Gorda ridge volcanism: new evidence from the 1996 eruption. Earth and Planetary Science Letters 206: 459-475

Cordier C, Caroff M, Juteau T, Fleutelot C, Hémond C, Drouin M, Cotten J, Bollinger C (2007) Bulk-rock geochemistry and plagioclase zoning in lavas exposed along the northern flank of the Western Blanco Depression (Northeast Pacific): Insight into open-system magma chamber processes. Lithos 99: 289-311

Cotsonika LA, Perfit MR, Smith MC, Kamenov GD, Stakes DS, Ridley WI, Wallace P (2005) The occurrence and origin of andesites and dacites from the Southern Juan de Fuca Ridge. Eos Transactions, American Geophysical Union, Fall Meeting Supplement 86 (18), Abstract V13A-04 
Davis AS, Clague DAC., Cousens BL, Keaten B, Paduan JB (2008) Geochemistry of basalt from the North Gorda segment of the Gorda Ridge: Evolution toward ultraslow spreading ridge lavas due to decreasing magma supply. Geochemistry Geophysics Geosystems 9, Q04004, doi: 10.1029/2007GC001775

De Paolo DJ (1981) Trace element and isotopic effects of combined wallrock assimilation and fractional crystallization. Earth and Planetary Science Letters 53: 189-202

Detrick RS, Buhl P, Vera EE, Mutter JC, Orcutt JA, Madsen JA, Brocher TM (1987) Multichannel seismic imaging of a crustal magma chamber along the East Pacific Rise. Nature 326: 35-41

Einaudi F, Godard M, Pezard PA, Cochemé JJ, Coulon C, Brewer T, Harvey P (2003) Magmatic cycles and formation of the upper oceanic crust at spreading centers: Geochemical study of a continuous extrusive section in the Oman ophiolite. Geochemistry Geophysics Geosystems 4, 8608, doi: 10.1029/2002GC000362

Embley RW, Wilson DS (1992) Morphology of the Blanco Transform Fault Zone-NE Pacific: Implications for its tectonic evolution. Marine Geophysical Researches 14: 25-45.

Fornari DJ, Perfit MR, Malahoff A, Embley RW (1983) Geochemical studies of abyssal lavas recovered by DSRV Alvin from eastern Galapagos rift, Inca transform and Ecuador rift 1. Major element variations in natural glasses and spacial distribution of lavas. Journal of Geophysical Research 88: 10519-10529

France L, Koepke J, Ildefonse B, Cichy SB, Deschamps F (2010) Hydrous partial melting in the sheeted dike complex at fast spreading ridges: experimental and natural observations. Contributions to Mineralogy and Petrology 160: 683-704

Fujimaki H, Tatsumoto M, Aoki KI (1984) Partition coefficients of Hf, Zr, and REE between phenocrysts and groundmasses. Lunar and Planetary Science Conference, 14th, Houston, TX, Journal of Geophysical Research, Supplement 89, B662-B672 
473 Garrido C, Kelemen P, Hirth G (2001) Variation of cooling rate with depth in lower crust formed at an oceanic spreading ridge: Plagioclase crystal size distributions in gabbros from the Oman ophiolite. Geochemistry Geophysics Geosystems 2, 1041, doi: $10.1029 / 2000 G C 000136$

Gillis KM, Coogan LA (2002) Anatectic migmatites from the roof of an ocean ridge magma chamber. Journal of Petrology 43: 2075-2095

Goldstein SJ, Murrell MT, Williams RW (1993) ${ }^{231} \mathrm{~Pa}$ and ${ }^{230} \mathrm{Th}$ chronology of mid-ocean ridge basalts. Earth and Planetary Science Letters 115: 151-159

Henstock TJ (2002) Compaction control of melt distribution at fast-spreading mid-ocean ridges. Geophysical Research Letters 29, 1137, doi: 10.1029/2001GL013755

Henstock TJ, Woods AW, White RS (1993) The accretion of oceanic crust by episodic sill intrusion. Journal of Geophysical Research 98: 4143-4161

Hooft EEE, Detrick RS, Kent GM (1997) Seismic structure and indicators of magma budget along the Southern East Pacific Rise. Journal of Geophysical Research 102: 2731927340

Hussenoeder SA, Collins JA, Kent GM, Detrick RS (1996) Seismic analysis of the axial magma chamber reflector along the southern East Pacific Rise from conventional reflection profiling. Journal of Geophysical Research 101: 22087-22105

Juteau T et al (1995) A submersible study in the Western Blanco Fracture Zone, N.E. Pacific: structure and evolution during the last 1.6 Ma. Marine Geophysical Researches 17: $399-430$

Karson JA et al (2002a) Structure of uppermost fast spread oceanic crust exposed at the Hess Deep Rift: Implications for subaxial processes at the East Pacific Rise. Geochemistry Geophysics Geosystems 3, 1002, doi: 10.1029/2001GC000155 
Karson JA, Maurice AT, Delaney JR (2002b) Internal structure of uppermost oceanic crust along the Western Blanco Transform Scarp: Implications for subaxial accretion and deformation at the Juan de Fuca Ridge. Journal of Geophysical Research 107, 2181, doi: 10.1029/2000JB000051

Kelemen PB, Koga KT, Shimizu N (1997) Geochemistry of gabbro sills in the crust/mantle transition zone of the Oman ophiolite: Implications for the origin of the oceanic lower crust. Earth and Planetary Science Letters 146: 475-488

Koepke J, Christie DM, Dziony W, Holtz F, Lattard D, Maclennan J, Park S, Scheibner B, Yamasaki T, Yamasaki S (2008) Petrography of the dike-gabbro transition at IODP Site 1256 (equatorial Pacific): The evolution of the granoblastic dikes. Geochemistry Geophysics Geosystems 9: Q07O09, doi: 10.1029/2008GC001939

Korenaga J, Kelemen PB (1998) Melt migration through the oceanic lower crust: A constraint from melt percolation modelling with finite solid diffusion. Earth and Planetary Science Letters 156: 1-11

Lagabrielle Y, Cormier M-H (1999) Formation of large summit troughs along the East Pacific Rise as collapse calderas: An evolutionary model. Journal of Geophysical Research 104: $12971-12988$

Langmuir CH (1989) Geochemical consequence of in situ crystallization. Nature 340: 199205

Manac'h G, Lécuyer C, Juteau T (1999) A fluid inclusion and stable isotope study of hydrothermal circulation in a transform zone: Western Blanco Depression, northeast Pacific. Journal of Geophysical Research 104: 12941-12970

Normark WR, Morton JL, Koski R, Clague DA (1983) Active hydrothermal vents and sulfide deposits on the southern Juan de Fuca Ridge. Geology 11: 158-163 
O’Hara MJ (1977) Geochemical evolution during fractional crystallization of a periodically refilled magma chamber. Nature 266: 503-507

O’Hara MJ, Mathews RE (1981) Geochemical evolution in an advancing, periodically replenished, periodically tapped, continuously fractionated magma chamber. Journal of the Geological Society of London 138: 237-277

Pallister JS, Hopson CA (1981) Samail Ophiolite plutonic suite: Field relations, phase variation, cryptic variation and layering, and a model of a spreading ridge magma chamber. Journal of Geophysical Research 86: 2593-2644

Perfit MR, Fornari DJ, Malahoff A, Embley RW (1983) Geochemical studies of abyssal lavas recovered by DSRV ALVIN from Eastern Galapagos Rift, Inca Transform, and Ecuador Rift, 3, Trace element abundances and petrogenesis. Journal of Geophysical Research 88: 10551-10572

Phipps Morgan J, Chen YJ (1993) The genesis of oceanic crust: Magma injection, hydrothermal circulation, and crustal flow. Journal of Geophysical Research 98: 62836297

Pollock MA, Klein EM, Karson JA, Tivey MA (2005) Temporal and spacial variability in the composition of lavas exposed along the Western Blanco Transform Fault. Geochemistry Geophysics Geosystems 6, Q11009, doi: 10.1029/2005GC001026

Pyle DM (1992) The volume and residence time of magma beneath active volcanoes determined by decay-series disequilibria methods. Earth and Planetary Science Letters 112: $61-73$

Quick JE, Denlinger RP (1993) Ductile deformation and the origin of layered gabbro in ophiolites. Journal of Geophysical Research 98: 14015-14027 
544 Rannou E, Caroff M, Cordier C (2006) A geochemical approach to model periodically replenished magma chambers: Does oscillatory supply account for the magmatic evolution of EPR 17-19 ${ }^{\circ}$ S? Geochimica et Cosmochimica Acta 70: 4783-4796

Reagan MK, Gill JB, Malavassi E, Garcia MO (1987) Changes in magma composition at Arenal volcano, Costa Rica, 1968-1985 : real-time monitoring of open-system differentiation. Bulletin of Volcanology 49: 415-434

Rubin KH, MacDougall JD (1990) Dating of neovolcanic MORB using $\left({ }^{226} \mathrm{Ra} /{ }^{230} \mathrm{Th}\right)$ disequilibrium. Earth and Planetary Science Letters 101: 313-322

Rubin KH, van Der Zander I, Smith MC, Bergmanis EC (2005) Minimum speed limit for ocean ridge magmatism from ${ }^{210} \mathrm{~Pb}-{ }^{226} \mathrm{Ra}-{ }^{230} \mathrm{Th}$ disequilibria. Nature 437: 534-538

Singh SC, Kent GM, Collier JS, Harding AJ, Orcutt JA (1998) Melt to mush variations in crustal magma properties along the ridge crest at the southern East Pacific Rise. Nature 394: 874-878.

Sinton JM, Detrick RS (1992) Mid-Ocean Ridge Magma Chambers. Journal of Geophysical Research 97: 197-216

Smewing JD (1981) Mixing characteristics and compositional differences in mantle-derived melts beneath spreading axes: evidence from cyclically layered rocks in the ophiolite of north Oman. Journal of Geophysical Research 86: 2645-2659

Smith MC, Perfit MR, Jonasson IR (1994) Petrology and geochemistry of basalts from the southern Juan de Fuca ridge: Controls on the spatial and temporal evolution of midocean ridge basalt. Journal of Geophysical Research 99: 4787-4812

Stakes DS, Perfit MR, Tivey MA, Caress DW, Ramirez TM, Maher N (2006) The Cleft revealed: Geologic, magnetic, and morphologic evidence for construction of upper oceanic crust along the southern Juan de Fuca Ridge. Geochemistry Geophysics Geosystems 7, Q04003, doi: 10.1029/2005GC001038 
Tivey MA (1996) Vertical magnetic structure of ocean crust determined from near-bottom magnetic field measurements. Journal of Geophysical Research 101: 20275-20296

Tivey MA, Johnson HP, Fleutelot C, Hussenoeder SA, Lawrence R, Waters C, Wooding, B (1998) Direct measurement of magnetic reversal polarity boundaries in a cross-section of oceanic crust. Geophysical Research Letters 25: 3631-3634

Volpe AM, Goldstein SJ (1993) ${ }^{226} \mathrm{Ra}^{230}$ Th disequilibrium in axial and off-axis mid-ocean ridge basalts. Geochimica et Cosmochimica Acta 57: 1233-1241

Wanless VD, Perfit MR, Ridley WI, Klein E (2010) Dacite petrogenesis on Mid-Ocean Ridges: Evidence for oceanic crustal melting and assimilation. Journal of Petrology 51: $2377-2410$

West M, Menke W, Tolstoy M (2003) Focused magma supply at the intersection of the Cobb hotspot and the Juan de Fuca ridge. Geophysical Research Letters 30: 1724

Wilson DS (1993) Confidence intervals for motion and deformation of the Juan de Fuca plate. Journal of Geophysical Research 98: 16053-16071

Wilson DS, Hey RN, Nishimura C (1984) Propagation as a mechanism of reorientation of Juan de Fuca Ridge. Journal of Geophysical Research 89: 9215-9225

Wilson DS et al (2006) Drilling to gabbro in intact ocean crust. Science 312: 1016-1020.

\section{Figure captions:}

Figure 1. Theoretical magma chamber considered in the mathematical modeling (a) and its adaptation to fit with the different mechanisms proposed for the accretion of the lower oceanic crust and for the related geometry of the magma chamber beneath fast to intermediate spreading ridges (b and c). In the "Gabbro glacier'” model (b), crystallization takes place in a thin sill at the base of the sheeted dike complex from which cumulates subside down 
594 (Henstock 2002; Henstock et al. 1993; Phipps Morgan and Chen 1993; Quick and Denlinger

595 1993). GG1 and GG2 refer to the two scenarios envisioned when discussing in the text the

596 volume of melt expellable from the reservoir (with or without the contribution of the

597 interstitial melt of the crystal mush, respectively). In the "Sheeted sill”' model (c), the lower

598 oceanic crust is formed through in situ crystallization of multiple sills (Boudier et al. 1996;

599 Garrido et al. 2001; Kelemen et al. 1997; Korenaga and Kelemen 1998). The volume of

600 expellable melt is then approached by considering the contribution of two melt lenses. The

601 different parameters are defined in Table 1: $Q$ refers to melt volumes, $C$ to element

602 concentrations, and the subscripts i, c and e to injected, crystallized and expelled,

603 respectively. The wide arrows show the main melt fluxes through the magmatic system.

604

605 Figure 2. Chemical evolution of the lavas collected along the Cleft segment and the Northern

606 Scarp of the Western Blanco Depression (WBD). a) Shaded relief bathymetry of the Cleft

607 segment and WBD with the location of the submersible dives along the Northern Scarp

608 (Cordier et al. 2007; Juteau et al. 1995) and of the Cleft segment samples (Smith et al. 1994;

609 Stakes et al. 2005). Inset: location map of the WBD in the NE Pacific. JdF R.: Juan de Fuca

610 ridge; G. R.: Gorda ridge; BTF: Blanco Transform Fault. b) Evolution of the MgO contents in

611 lavas with latitude. c) $\mathrm{TiO}_{2}$ versus $\mathrm{MgO}$ diagram. Samples used in the model resolution are

612 labeled and their composition is listed in Table 2. Chemical data are from the literature (Smith

613 et al. 1994; Stakes et al. 2005; Cordier et al., 2007).

614

615 Figure 3. Chemical evolution with depth in the extrusive unit of the Northern Scarp for two 616 groups of dives, located ca. 25 and $40 \mathrm{~km}$ eastward from the Juan de Fuca axis, respectively.

617 a) Lithologies observed along the Northern Scarp superimposed on the magnetic cross section

618 (Tivey 1996; Tivey et al. 1998). Normal polarity crust is shaded in light gray (M: Matuyama) 
and inverse polarity crust in dark gray (B: Brunhes, J: Jaramillo, 2: Anomaly 2). The filled stars show the position of the dives illustrated in b). b) Variations of La with depth. They are consistent with those of Mg\# shown in Cordier et al. (2007) (their Fig, 10). The changes from mafic (low La contents) to intermediate or evolved terms (high La contents) are thought to result from fractional crystallization, followed by returns to mafic compositions during replenishment events.

Figure 4. Resolution procedure of the model of Rannou et al. (2006). Parameters are defined in Table 1. In the step 1, Eq. 1 is modified after Eq. 12 of Rannou et al. (2006). $\omega$ is fixed arbitrarily to $2 \pi$. $f$ and $z^{\mathrm{E}}$ are new parameters with respect to the model of Rannou et al. (2006) and are used to model the mixing between the interstitial residual melts of the crystal mush zones and the melt residing in the lens.

Figure 5. Effect of the variation of the parameters $C^{\mathrm{E}}{ }_{\max }, f$ and $Q_{\max }-Q_{\min }$ on the REE concentration in lavas ( $a$ and b) and on the resident melt volume (c and d). La is shown as an example of the REE concentrations in lavas. The curves are drawn using Eq. 1 and Eq. 6 (Fig. 4). The parameters $C^{\mathrm{La}}{ }_{\min }(3.1 \mu \mathrm{g} / \mathrm{g}), r_{\mathrm{e}}(0.4)$ and $\left[q_{\mathrm{i}}\right]\left(0.004 \mathrm{~km}^{3} / \mathrm{yr} .10 \mathrm{~km}\right)$ are similar in the different illustrated cases. The values of $f, C^{\mathrm{E}}{ }_{\max }$ and $Q_{\max }-Q_{\min }$ used in each case are stated on the figure. $f$ is the fraction of interstitial melt migrating from the solidification zone into the melt lens. $f=1$ when the melt lens collects the entire volume of the melts that have evolved in the solidification zones (perfect fractional crystallization). $f=0.5$ when half of the melts that have evolved in the solidification zones are injected within the melt lens. The results for each calculation are listed in Table 3. The model does not give suitable solution for $f=0.5$ and $C_{\text {max }}^{\mathrm{La}}=20.6 \mu \mathrm{g} / \mathrm{g}(\mathrm{b})$ 
644 Figure 6. Chemical compositions used for the model resolution and results of the first step of 645 the modeling. (a) The range of REE compositions of the Northern Scarp lavas, the $C^{\mathrm{E}}$ min and $646 C_{\text {max }}^{\mathrm{E}}$ used in the modeling (listed in Table 2) and the Mg\#70 melt composition deduced by 647 Cordier et al. (2007) from petrological and geochemical data are shown. (b) Composition of 648 the replenishment melt $\left(C^{\mathrm{E}}{ }_{\mathrm{i}}\right.$, Table 3$)$ together with the lava range (see text). $C^{\mathrm{E}}{ }_{\mathrm{i}}$ are calculated 649 graphically for each REE by introducing into Eq. 1 of Fig. 4 the following parameters: $r_{\mathrm{e}}=$ $6500.4 ; C_{\text {max }}^{\mathrm{E}}=\mathrm{REE}$ contents in Fe-basalt and andesite, respectively (Table 2); $f=0.5$ and $f=1$. 651 The theoretical $C^{\mathrm{E}}{ }_{\text {i }}$ patterns have lower REE contents than the lavas and are slightly more

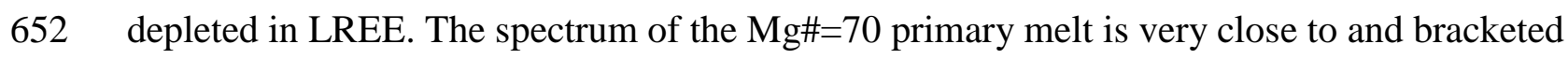
653 by our theoretical refilling melts. The model does not give suitable $C^{\mathrm{E}}$ i pattern for $f=0.5$ and $654 C^{\mathrm{E}}{ }_{\max }($ andesite).

655 
Table 1. Definition of the model parameters.

\begin{tabular}{|c|c|c|}
\hline Parameters & Values $^{\mathrm{a}}$ & Definition \\
\hline$\overline{C_{\text {max }}^{\mathrm{E}}(\mu \mathrm{g} / \mathrm{g})}$ & Table 2 & Concentration of the rare earth element $\mathrm{E}$ in the most evolved lava \\
\hline$C^{\mathrm{E}}{ }_{\min }(\mu \mathrm{g} / \mathrm{g})$ & Table 2 & Concentration of $\mathrm{E}$ in the most mafic lava \\
\hline$C_{i}^{\mathrm{E}}(\mu \mathrm{g} / \mathrm{g})$ & & Concentration of $\mathrm{E}$ in the refilling melt \\
\hline$D^{\mathrm{E}}$ & Table 2 & Bulk distribution coefficient of $\mathrm{E}$ \\
\hline$f^{b}$ & 0.5 and 1 & Fraction of melt evolving in the solidification zones and reintroduced in the melt lens \\
\hline$z^{\mathrm{Eb}}$ & Table 2 & $\begin{array}{l}\text { Coefficient accounting for melt differentiation due to fractional crystallization and } \\
\text { possible chemical exchanges between melt and crystals in crystal mush }\end{array}$ \\
\hline$\left[q_{i}\right]\left(\mathrm{km}^{3} / \mathrm{yr} .10 \mathrm{~km}\right)^{\mathrm{c}}$ & 0.004 & Average rate of melt input in the reservoir \\
\hline$\alpha\left(\mathrm{yr}^{-1}\right)$ & & Average crystallization rate: fraction of melt crystallized per time unit \\
\hline$\omega / 2 \pi(\mathrm{Hz})$ & & Frequency of the replenishment, with $\omega$ the pulsation of the replenishment \\
\hline$\beta^{\mathrm{E}}$ & & Internal parameter iteratively estimated for each $\mathrm{E}$, the average of which gives $\beta_{\mathrm{av}}$ \\
\hline$\beta_{\mathrm{av}}$ & & Ratio between pulsation $(\omega)$ and crystallization rate $(\alpha)$, average of the $\beta^{\mathrm{E}}$ values \\
\hline & 0.4 & Mean ratio between average extrusion and crystallization rates \\
\hline$Q\left(\mathrm{~km}^{3} / \mathrm{yr} .10 \mathrm{~km}\right)^{\mathrm{c}}$ & & Volume of melt residing (i.e. expellable) in the reservoir \\
\hline$Q_{\max }-Q_{\min }\left(\mathrm{km}^{3} / 10 \mathrm{~km}\right)^{\mathrm{c}}$ & 0.45 to 0.90 & Amplitude of the variations of the melt volume in the reservoir \\
\hline$T(\mathrm{yr})$ & & Period of the replenishment \\
\hline$\tau(\mathrm{yr})$ & & Average magma residence time \\
\hline
\end{tabular}

${ }^{\mathrm{a}}$ Values introduced into the resolution procedure are stated here when constant for the different REEs. Otherwise, they are listed in Table 2.

${ }^{\mathrm{b}}$ Parameters adapted from the equations of in situ crystallization of Langmuir (1989).

${ }^{\mathrm{c}}$ Units are expressed for a $10 \mathrm{~km}$-long magma chamber, as typically observed beneath the Cleft segment. See text. 
Table 2. Chemical input parameters.

\begin{tabular}{|c|c|c|c|c|c|c|c|c|}
\hline Sample & 2960-7 & BN02-12 & 999-1B & RC-10 & & & & \\
\hline Parameter $^{\mathrm{a}}$ & $C^{\mathrm{E}}{ }_{\min }$ & $C_{\max }^{\mathrm{E}}$ & $C_{\text {max }}^{\mathrm{E}}$ & & $z_{1}^{\mathrm{E} b}$ & $z_{2}^{\mathrm{E} \mathrm{b}}$ & $\mathrm{z}_{1}^{\mathrm{E} \mathrm{b}}$ & $\mathrm{z}_{2}^{\mathrm{Eb}}$ \\
\hline Type $^{c}$ & Bas. & Fe-bas. & And. & Dac. & $\rightarrow$ Fe-bas. & $\rightarrow$ And. & $\rightarrow$ Fe-bas. & $\rightarrow$ And. \\
\hline & & & & & 1 & 1 & 0.5 & 0.5 \\
\hline Loc. $^{\mathrm{d}}$ & NS & NS & Galap. & Cleft & & & & \\
\hline Analysis $^{\mathrm{e}}$ & WR & WR & GL & GL & & & & \\
\hline Ref. $^{\text {f }}$ & 1 & 1 & 2 & 3 & & & & \\
\hline $\mathrm{SiO}_{2}$ (wt. \% & 49.50 & 48.85 & 56.70 & 63.15 & & & & \\
\hline $\mathrm{TiO}_{2}$ & 1.36 & 3.61 & 1.91 & 1.29 & & & & \\
\hline $\mathrm{Al}_{2} \mathrm{O}_{3}$ & 15.15 & 11.62 & 11.42 & 12.47 & & & & \\
\hline $\mathrm{Fe}_{2} \mathrm{O}_{3}{ }^{\text {tot } \mathrm{g}}$ & 10.80 & 19.10 & 17.98 & 11.84 & & & & \\
\hline $\mathrm{MnO}$ & 0.19 & 0.26 & 0.29 & 0.18 & & & & \\
\hline $\mathrm{MgO}$ & 8.05 & 4.27 & 1.80 & 1.13 & & & & \\
\hline $\mathrm{CaO}$ & 12.00 & 7.78 & 6.90 & 4.52 & & & & \\
\hline $\mathrm{Na}_{2} \mathrm{O}$ & 2.30 & 3.10 & 3.48 & 4.43 & & & & \\
\hline $\mathrm{K}_{2} \mathrm{O}$ & 0.15 & 0.34 & 0.39 & 0.98 & & & & \\
\hline $\mathrm{P}_{2} \mathrm{O}_{5}$ & 0.14 & 0.52 & 0.65 & - & & & & \\
\hline LOI & -0.15 & 1.08 & - & - & & & & \\
\hline Total & 99.49 & 100.53 & 101.52 & 99.99 & & & & \\
\hline $\mathrm{Mg}^{\mathrm{h}}$ & 64.85 & 35.62 & 22.07 & 23.95 & & & & \\
\hline $\mathrm{La}(\mu \mathrm{g} / \mathrm{g})$ & 3.1 & 13.3 & 20.6 & & 0.06 & 0.09 & 0.11 & 0.16 \\
\hline $\mathrm{Ce}$ & 9.6 & 42 & 61 & & 0.06 & 0.10 & 0.11 & 0.19 \\
\hline $\mathrm{Nd}$ & 8.3 & 40 & 58 & & 0.11 & 0.18 & 0.20 & 0.30 \\
\hline Sm & 3.05 & - & 18.2 & & 0.17 & 0.27 & 0.30 & 0.42 \\
\hline $\mathrm{Eu}$ & 1.09 & 3.30 & 4.82 & & 0.21 & 0.29 & 0.35 & 0.45 \\
\hline $\mathrm{Gd}$ & 4.25 & - & 23.5 & & 0.22 & 0.32 & 0.35 & 0.49 \\
\hline Dy & 5.25 & 16.2 & 27.0 & & 0.22 & 0.33 & 0.37 & 0.50 \\
\hline Er & 3.10 & 10.7 & 18.8 & & 0.23 & 0.33 & 0.37 & 0.49 \\
\hline $\mathrm{Yb}$ & 3.10 & 9.65 & 17.6 & & 0.22 & 0.30 & 0.36 & 0.46 \\
\hline
\end{tabular}

${ }^{\mathrm{a}}$ Parameters are defined in Table 1.

${ }^{\mathrm{b}}$ The $z^{\mathrm{E}}$ values are calculated from the bulk partition coefficients $D^{\mathrm{E}}$ (Table 1), considering two $f$ values ( 1 and 0.5 ) and two cumulate modal compositions: $0.10 \mathrm{ol}+0.35 \mathrm{cpx}+0.55$ plag for $z_{1}{ }^{\mathrm{E}}$ (Rannou et al. 2006) and $0.043 \mathrm{ol}+0.447 \mathrm{cpx}+0.452 \mathrm{plag}+0.055 \mathrm{tmt}+0.003$ ap for $z_{2}^{\mathrm{E}}$ (Perfit et al. 1983). Note that when $f=1, z^{\mathrm{E}}$ and $D^{\mathrm{E}}$ are equivalent.

${ }^{\mathrm{c}}$ Bas. $=$ basalt; Fe-bas. $=$ ferrobasalt; And. $=$ andesite; Dac. $=$ dacite.

${ }^{\mathrm{d}}$ Location: NS = Northern Scarp; Galap. $=$ Eastern Galapagos rift; Cleft $=$ south Cleft segment.

${ }^{\mathrm{e}} \mathrm{WR}=$ whole-rock analysis (ICP-AES); GL = glass analysis (EPMA).

${ }^{\mathrm{f}}$ References: 1. Cordier et al. (2007); 2. Fornari et al. (1983) and Perfit et al. (1983); 3. Stakes et al. (2006).

${ }^{\mathrm{g}}$ All Iron as $\mathrm{Fe}_{2} \mathrm{O}_{3}{ }^{\text {tot }}$.

${ }^{\mathrm{h}} \mathrm{Mg \#}$ is calculated using a $\mathrm{Fe}_{2} \mathrm{O}_{3} / \mathrm{FeO}$ ratio of $0.2,0.3$ and 0.4 for basalt/ferrobasalt, andesite, and dacite, respectively. 
Table 3. Results of the modeling for the Cleft segment magma system in function of different values of $C^{\mathrm{E}}{ }_{\max }, f$ and $Q_{\max }-Q_{\min }$ but similar values of $C^{\mathrm{E}}$ min $($ Table 2$), r_{\mathrm{e}}(0.4)$ and $\left[q_{\mathrm{i}}\right](0.004$

$\mathrm{km} 3 / \mathrm{yr} .10 \mathrm{~km})$.

\begin{tabular}{lllll}
\hline$C^{\mathrm{E}}{ }_{\max }^{1}$ & Fe-bas & Fe-bas & Andesite & $\mathrm{Mg \# =70}$ \\
$f$ & 1 & 0.5 & 1 & \\
\hline
\end{tabular}

Step 1: Composition of the modeled replenishment melt

$\begin{array}{lllll}\mathrm{La}(\mu \mathrm{g} / \mathrm{g}) & 1.42 & 1.54 & 1.52 & 1.35 \\ \mathrm{Ce} & 4.41 & 4.82 & 4.85 & 4.37 \\ \mathrm{Nd} & 4.19 & 4.75 & 4.67 & 4.13 \\ \mathrm{Sm} & & & 1.90 & \\ \mathrm{Eu} & 0.62 & 0.72 & 0.70 & 0.69 \\ \mathrm{Gd} & & & 2.80 & \\ \mathrm{Dy} & 3.03 & 3.56 & 3.50 & 3.08 \\ \mathrm{Er} & 1.82 & 2.13 & 2.05 & 1.90 \\ \mathrm{Yb} & 1.78 & 2.09 & 2.02 & 1.83 \\ \beta^{\mathrm{REE}} & 0.930-1.285 & 0.715-1.048 & 0.141-0.730 & \\ \beta_{\mathrm{av}} & 1.137 & 0.899 & 0.467 & \\ \sigma\left(\beta_{\text {av }}\right) & 0.119 & 0.124 & 0.200 & \end{array}$

Step 2: Crystallization rate $(\alpha)$, period $(T)$, residence time $(\tau)$ $\mathrm{GG}^{3}, Q_{\max }-Q_{\min }=0.45 \mathrm{~km}^{3} / 10 \mathrm{~km}$

$\begin{array}{llll}\alpha\left(\mathrm{yr}^{-1}\right) & 0.0099 & 0.0107 & 0.0121 \\ T(\mathrm{yr}) & 561 & 654 & 1118 \\ \tau(\mathrm{yr}) & 72 & 67 & 59\end{array}$

$\mathrm{GG}^{3}, Q_{\max }-Q_{\min }=0.63 \mathrm{~km}^{3} / 10 \mathrm{~km}$

$\begin{array}{llll}\alpha & 0.0070 & 0.0076 & 0.0086 \\ T & 785 & 916 & 1565 \\ \tau & 101 & 94 & 83\end{array}$

$\begin{array}{clll}\mathrm{SS}^{3}, Q_{\max }-Q_{\min }= & 0.9 \mathrm{~km}^{3} / 10 \mathrm{~km} & \\ \alpha & 0.0049 & 0.0053 & 0.0060 \\ T & 1122 & 1308 & 2235 \\ \tau & 145 & 134 & 119\end{array}$

${ } C_{\text {max }}$ : composition of the most evolved lava considered in our calculations. ${ }^{2} \sigma\left(\beta_{\mathrm{av}}\right)$ : standard deviation of the $\beta^{\mathrm{E}}$ values deduced from the different REE.

${ }^{3}$ GG: gabbro glacier model for the magma chamber, by ignoring or considering the partial draining of the crystal much lying beneath the melt lens; SS: sheeted sill model. See text for the estimation of the different volumes. 
a) Theoretical magma chamber
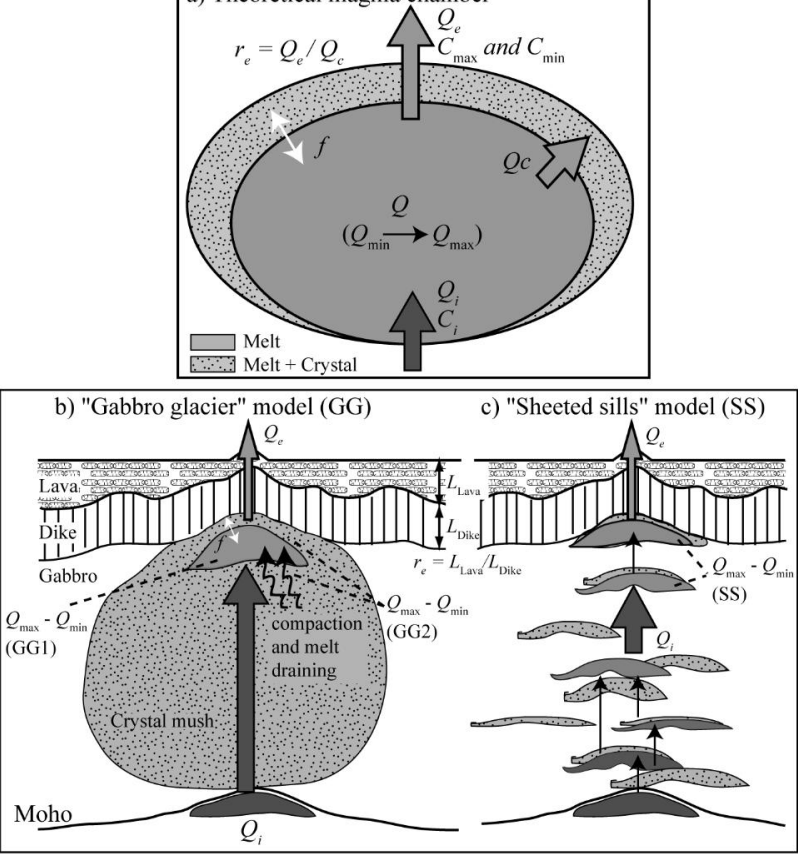

Cordier et al.

Figure 1 

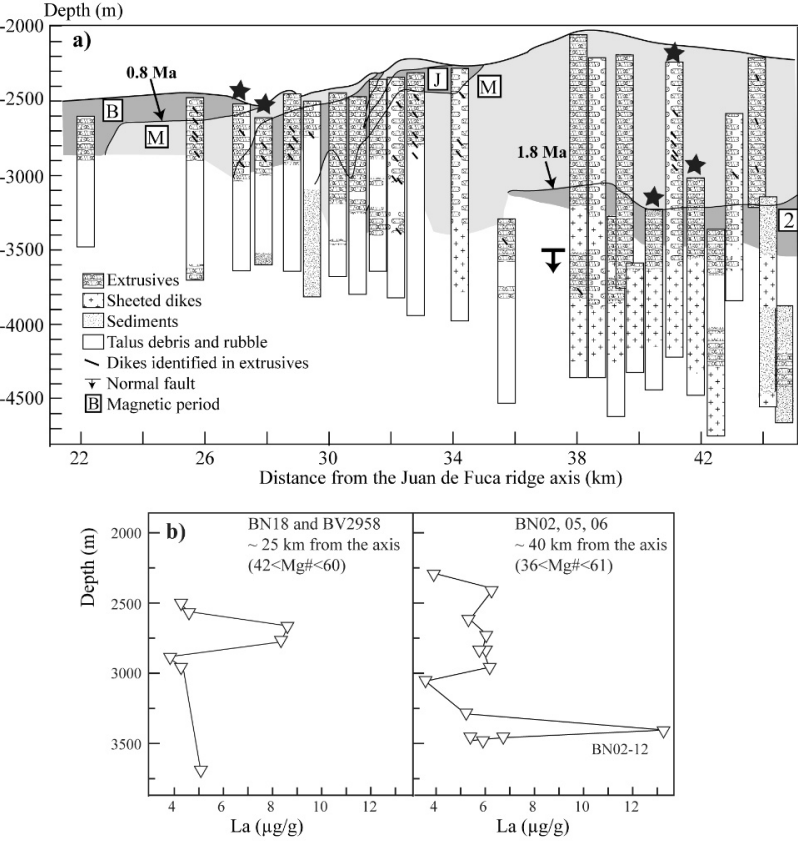

Figure 3

Cordier et al. 
(a) Step 1: Geochemical approach

\section{Required} parameters:

$C_{\text {min }}^{\mathrm{E}}$
$C_{\text {max }}^{\mathrm{E}}$
$D^{\mathrm{E}}$
$r_{\mathrm{c}}$
$f$

Eq. 1: $C^{\mathrm{E}}(t)=C_{i}^{\mathrm{E}}$

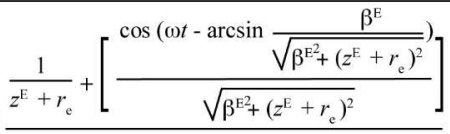

$$
\frac{1}{1+r_{\mathrm{e}}}+\left[\frac{\cos \left(\omega t-\arcsin \frac{\beta^{\mathrm{E}}}{\sqrt{\beta^{\mathrm{E}^{2}+\left(1+r_{\mathrm{e}}\right)^{2}}}}\right]}{\sqrt{{\beta^{2}+\left(1+r_{\mathrm{e}}\right)^{2}}^{2}}}\right]
$$

With Eq. 2: $z^{\mathrm{E}}=\frac{D^{\mathrm{E}}}{D^{\mathrm{E}}(1-f)+f}$

\section{(b) Step 2: Temporal approach}

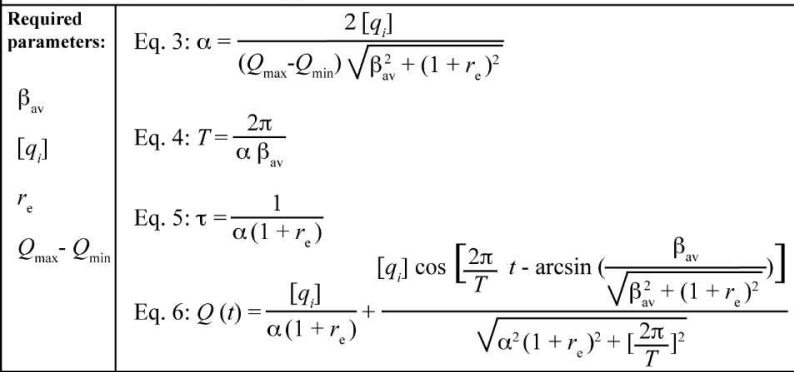

Results: $\alpha, T, \tau$, and $Q$

Figure 4

Cordier et al. 
Rock/Chondrites

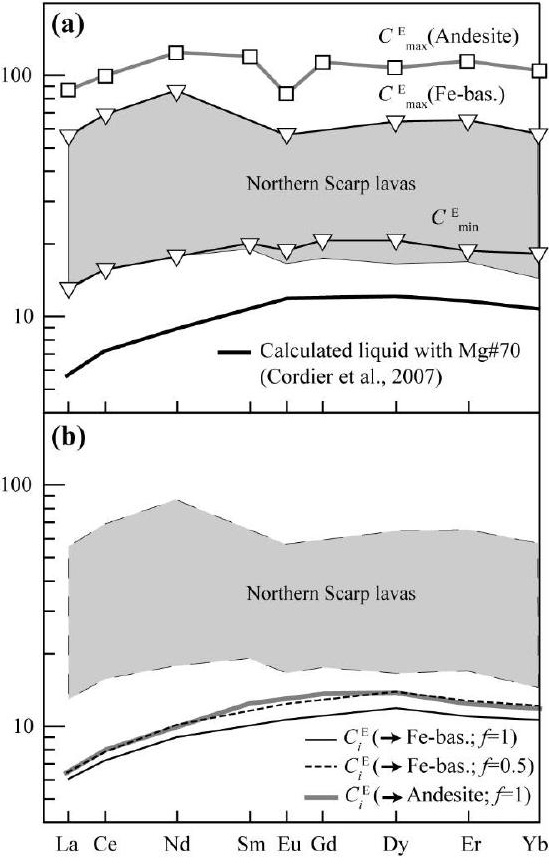

Cordier et al.

Figure 6 